\title{
Media campaigns promote driver safety for farmworkers
}

\author{
James I. Grieshop $\quad \square \quad$ Myriam Grajales-Hall $\square \quad$ Lupe Ortiz
}

\begin{abstract}
During the peak harvest season from April to October, hundreds of thousands of San Joaquin Valley farmworkers commute from field to field and farm to farm, sometimes two or three times a day. Motor vehicle crashes the largest documented cause of injuries and fatalities to farmworkers - increase dramatically at this time. To educate farmworker families about motor vehicle safety, we designed a program called ;Maneje Seguro! (Drive Safely!). Its centerpiece was a game, La Loteria del Manejo Seguro, based on a bingo-like game popular in Mexico (known simply as La Loteria). We disseminated safe-driving information by featuring the game in weekly bilingual newspapers and on Spanish radio and TV stations. Assessments suggest that media campaigns had favorable impact on farmworker knowledge, awareness and, to some degree, driving behavior.
\end{abstract}

California's agricultural system, among the most productive in the world, depends to a large degree on permanent, seasonal and contracted laborers. These workers perform many tasks required for the system's success. The Farmworker Service Coordinating Council estimates that between 900,000 and 1 million temporary, migratory and often foreign workers served California in 1992 (Martin 1992). Because of the nature of California farm work, farmworkers must be highly mobile. A large but undetermined number annually move from Mexico to California. Many more move within California and from other states to California. During the peak agricultural season, hundreds of thousands of workers move on a daily basis, "commuting" from field to field and farm to farm, sometimes two or three times per day. Many are transported by labor contractors, while others drive their own vehicles.

This worker group is largely of Hispanic-Mexican origin. More than $90 \%$ of these workers and their families were born and educated in Mexico. Two-thirds reportedly are monolingual Spanish speakers. In the San Joaquin Valley region of Fresno, Tulare, Kings, Madera and Merced counties, $40 \%$ - or 631,600 - of the total 1,579,000 inhabitants are Hispanic (Strategy Research Corporation 1996). Many work in agriculture and drive to their employment sites.

\section{Motor vehicle safety}

Since the early 1990s the health and safety of this population, both California-based and transnational, have attracted more public scrutiny. State and federal regulations now require that producers provide training to promote the health and well-being of these workers. Even though California has one of the best and most comprehensive agricultural workplace health and safety programs, problems remain. For example, motor vehicle crashes are the single largest cause of farmworker injuries and fatalities occurring on the farm (AgSafe 1992).

There is also an increasing number of crashes and fatalities that are not strictly work-related, but occur as farmworkers commute to and from work. The reasons are several: Drivers, who may be farmworkers or unlicensed farm labor contractors, often do not have valid driver licenses and are unfamiliar with California traffic

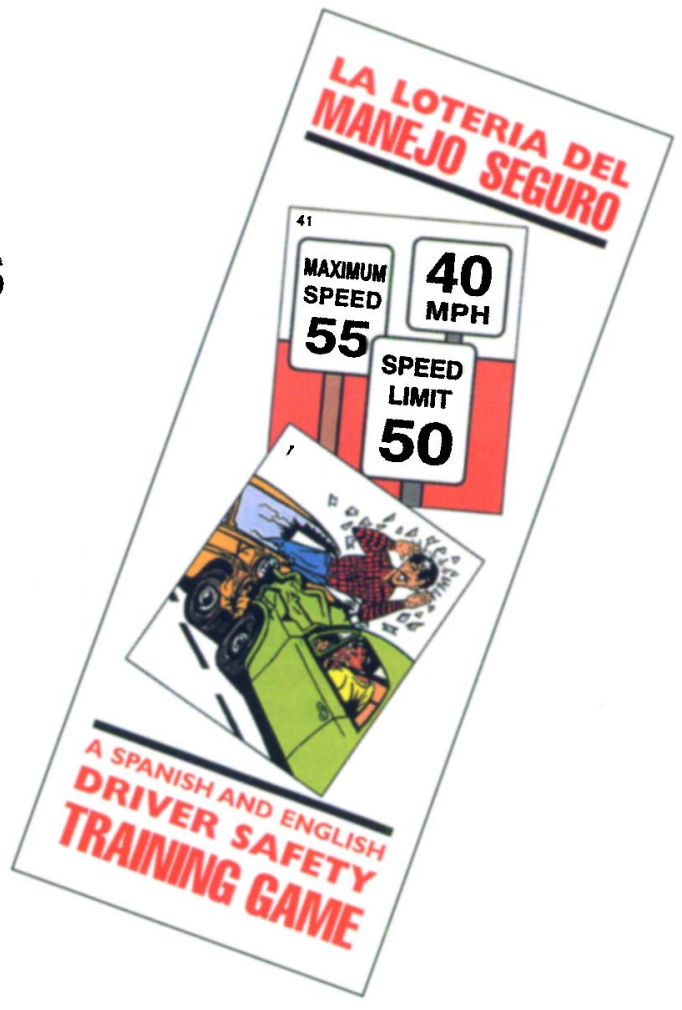

laws and passenger safety requirements. They may have little or no English proficiency. Where unlicensed contractors are involved, large passenger vehicles may not have been inspected in conformance with state law

Annual reports from the California Highway Patrol (CHP) reveal that the likelihood of dying on the roads in the Central Valley is more than three times greater than in other parts of California. In 1993 alone nearly 35,000 people were injured and 900 people died in motor vehicle crashes in the Central Valley (CHP 1993). In the Hispanic population of that area, the vehicle fatality rates are far higher than would be expected. Although Hispanics constituted $30 \%$ of the nine-county Central Valley population in 1990 , Hispanic traffic fatalities were $42 \%$ of the total in 1990 and $41 \%$ in 1991. Those figures were up from $33 \%$ in 1989. Also significant is the fact, again according to the $\mathrm{CHP}$, that the incidence of injuries and fatalities increases dramatically with the arrival of farmworkers from Mexico and other places from April to October. The Fresno Bee reported that in September 1995, in Madera County alone, 12 farmworkers were killed in five separate accidents while they were going to or returning from farm fieldwork. In the spring of 1996, another 11 farmworkers were killed in four acci- 
dents in the Fresno area

(Clemings 1996).

The incidents raise perplexing questions. Since many fatal crashes and fatalities are not strictly work-related, although they may occur during commutes, who should bear responsibility for addressing this public health issue? Who should intervene?

Possible candidates are law enforcement officials, growers, farm labor contractors, farmworker advocates, engineers and educators. Enforcement agents - such as the $\mathrm{CHP}$, the county sheriff and judges - could collaborate with growers and farmworker advocates to aggressively identify unlicensed farm labor contractors and require them to complete necessary training. Engineers could ensure that farmworkers' vehicles are in good condition, improve road signs and engineer new transportation systems for workers. Educators could provide safedriving information, train the trainers and inform Californians at large about this public safety issue.

In the study reported here, we developed and evaluated a community education program designed to improve safe driving among farmworker families.

\section{Developing ¡Maneje Seguro!}

The immediate need for bilingual, culturally sensitive products and promotional activities for the Spanishspeaking farmworker audience emerged from research we conducted in 1993. That research provided the rationale for our community education program, and led to 1994 funding of the program by the state Office of Traffic Safety (Grieshop and Stiles 1994). One principal finding was that San Joaquin Valley CHP officials reported encountering many drivers who did not speak English and might not be literate in their native language (CHP 1993). They often didn't know driving rules nor understand common road signs and principles of hazard
LA LOTERIA DEL MAMEJO SEGURO

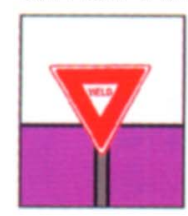

32. Ceda ol Paso

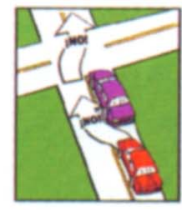

21. No Rebasar

en Crucero

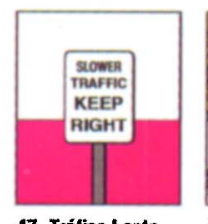

47. Tráfico Lento. a la Derecta

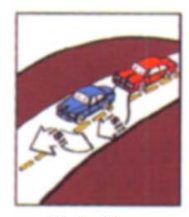
15. La Linea Quebrada
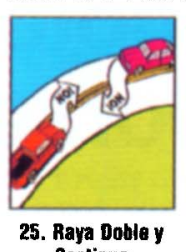

Continua

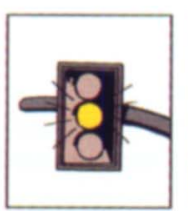

53. La Luz

Amarlla

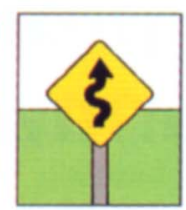

45. Camino

Sinueso

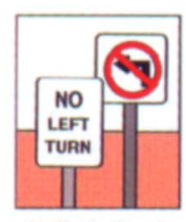

40. No Vuelta a la

izquierda

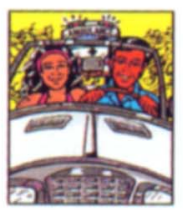

7. Aucho Yolumen

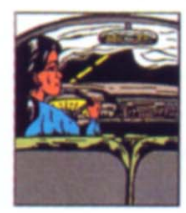

13. La Neblina

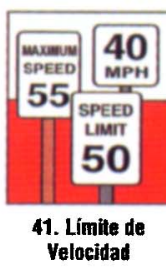

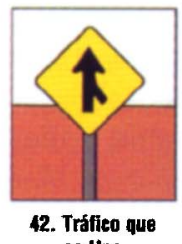

se Une
Tabla 15

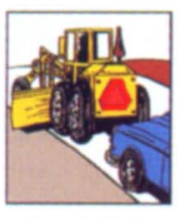

17. Maquinaria

Agricola

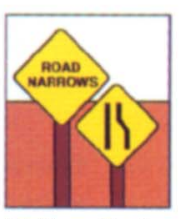

27. Menos Carriles Adelante

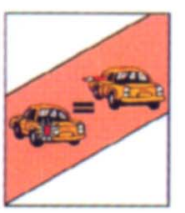

35. Seffal de Mano Izquierta

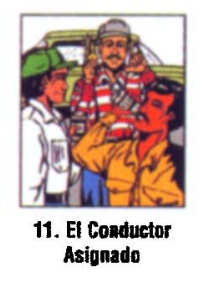

tions and signs; each card is accompanied by a descriptive rhyme in Spanish. Sixteen larger playing cards with combinations of the 54 pictures are used by players as "bingotype" cards. A trainer's/ player's manual, in both Spanish and English, completes the set.

Farmworkers and highschool-aged youth from farmworker families helped design the game, including the pictures, the phrasing of rhymes and the subject matter for a number of the picture cards. We also consulted this group on the game's acceptability and appropriateness. We knew from this product development research that the game held high cultural relevancy for our target audience of Hispanic farmworkers, and that they would find it intrinsically rewarding to play. In addition, because we knew that our target audience needed safety items, we offered child safety seats as

prevention. Drivers involved in major motor-vehicle accidents were often unlicensed and uninsured. Research has since shown that this population uses seat belts less frequently ( $45 \%$ compared to $65 \%$ of the general population) and seldom owns child safety seats (Stiles and Grieshop, 1997).

Other CHP figures reveal that while Hispanics account for $26 \%$ of the state's population, they make up $45 \%$ of misdemeanor drunken driving arrests.

The initial challenges to the ¡Maneje Seguro! educators were to discover and develop effective methods to reach this highly mobile population in ways that were appropriate and acceptable, yet efficient and effective.

Our original design effort led to the publication of La Loteria del Manejo Seguro (Stiles et al. 1994), an educational driver-safety game modeled on a popular Mexican game (La Loteria) similar to bingo. Each La Loteria del Manejo Seguro game contains 54 brightly colored picture cards that depict safe driving behaviors, regula- prizes.

In 1995 we initiated the ¡Maneje Seguro! community education program with a grant from the state Office of Traffic Safety. The program would. actively disseminate the contents of the game in novel ways to increase knowledge and understanding of safe driving by Spanish-speaking drivers and, ultimately, to improve their driving practices.

The community education program included a train-the-trainer program, in Spanish, for high-school and college students and community members from farmworker families. Trainees were taught how to use and adapt the game, how to teach effectively in informal learning settings and how to access community resources. These trained program extenders offered bilingual and Spanish-language safedriving (¡Maneje Seguro!) information within English as a Second Language (ESL) and citizenship classes, schools, migrant parent meetings and labor camps. Other training programs were 
offered by staff at farm sites, migrant labor centers, Farm Bureau emergency response classes, California Highway Patrol programs and traffic violator schools in the Central Valley.

In 1996, three community festivals, or fiestas, were organized with farmworker families and public officials. Driver safety was encouraged through youth-developed skits (teatros), writing contests, and with the involvement of local elected officials. Citizens and businesses donated infant and toddler car seats, thereby providing farmworker families with an important safety device otherwise not readily available to them. The ¡Maneje Seguro! program was also promoted in community events such as Cinco de Mayo and Mexican Independence Day. All of these educational events were designed to convey safe-driving information to farmworkers and other Spanish-speakers in familiar settings using familiar approaches.

\section{Mass media campaigns}

Two mass-media campaigns carried out in 1995 and 1996 were another core element of the ¡Maneje Seguro! program. Both campaigns were centered in the Fresno media market to coincide with the agricultural seasons, when large numbers of migrant workers and families work in the Central Valley. The campaigns were organized as coordinated contests involving Fresnobased Spanish-language newspapers, radio and TV. Radio and TV were selected as the principal means for reaching the Spanish-speaking audience, based partially on the knowledge that these two media are preferred by this audience. The audience targeted for the two campaigns was the Spanishdominant group. According to a Strategy Research Corporation study on the U.S. Hispanic Market, Spanishdominant Hispanics spend 69 hours weekly with Spanish media, versus 35 hours per week for thertotal HispanicAmerican population (Strategy Research Corporation 1996.). Among Spanish-dominant media users, $99.6 \%$ use TV and $93.6 \%$ use radio, compared to $81.7 \%$ and $71.6 \%$ for all Hispanics. Newspapers use, on the other hand, is $58.5 \%$ for Spanish-dominant versus $43.6 \%$ for all Hispanics.
For both campaigns, Loteria pictures and rhymes were printed in weekly bilingual newspapers read by the targeted audiences. Subsequently the game was "played" on Spanish radio and TV stations. The campaigns' goals were to extend specific and timely safety information to large targeted audiences; to engage segments of the Spanish-language listening and viewing audiences in thinking about driving safety; and to distribute useful prize materials, such as child car safety seats, to farmworker families.

\section{"Playing the game"}

Both campaigns were designed to deliver specific messages through the preferred media of farmworkers and the larger Spanish-speaking population in the Fresno area. Approximately $40 \%$ of the Fresno media market population is Spanish-speaking. In this market, several weekly bilingual newspapers deliver news and information to that community. Similarly, a number of Spanish-language radio and TV stations serve the Spanish-language community. For the campaigns, we recruited two newspapers (Vida en el Valle and EI Sol del Valle) to participate in the campaigns. Both newspapers published materials over an 8-week period, donating all materials and

TABLE 1. Outcomes of media campaigns

\begin{tabular}{|c|c|c|}
\hline & $\begin{array}{c}\text { Campaign I } \\
1995\end{array}$ & $\begin{array}{c}\text { Campaign II } \\
1996 \\
\end{array}$ \\
\hline Number of winners & 27 & 58 \\
\hline Number interviewed & $13(48 \%)$ & $31(53 \%)$ \\
\hline \multicolumn{3}{|l|}{$\begin{array}{l}\text { Number who reported that } \\
\text { they or spouse did }\end{array}$} \\
\hline \multicolumn{3}{|c|}{ How first learned of Loteria campaign } \\
\hline $\begin{array}{l}\text { From radio } \\
\text { From TV } \\
\text { From newspaper } \\
\text { Combination }\end{array}$ & $\begin{array}{r}7(54 \%) \\
1(7 \%) \\
2(14 \%) \\
3(23 \%)\end{array}$ & $\begin{array}{r}22(71 \%) \\
3(10 \%) \\
3(10 \%) \\
3(10 \%)\end{array}$ \\
\hline \multicolumn{3}{|l|}{ Number who could recall } \\
\hline $\begin{array}{l}\text { Picture title } \\
\text { Saying/rhyme } \\
\text { Safety tips } \\
\text { Other titles }\end{array}$ & $\begin{array}{c}11(85 \%) \\
0 \\
3(23 \%) \\
8(62 \%)\end{array}$ & $\begin{array}{r}28(90 \%) \\
1(3 \%) \\
22(71 \%) \\
12(39 \%)\end{array}$ \\
\hline \multicolumn{3}{|c|}{$\begin{array}{l}\text { Number who claimed other family } \\
\text { members or acquaintances } \\
\text { were specifically affected }\end{array}$} \\
\hline \multicolumn{3}{|c|}{$\begin{array}{l}\text { Number who reported change } \\
\text { in driving behavior }\end{array}$} \\
\hline $\begin{array}{l}\text { Self, specific behavior } \\
\text { Self, general behaviors } \\
\text { No change } \\
\text { Don't drive }\end{array}$ & $\begin{array}{r}4(31 \%) \\
6(46 \%) \\
1(8 \%) \\
2(16 \%)\end{array}$ & $\begin{array}{r}12(39 \%) \\
8(26 \%) \\
2(6 \%) \\
9(29 \%)\end{array}$ \\
\hline
\end{tabular}

work for both campaigns, for more than $\$ 18,000$ estimated combined equivalent value.

Both the radio station (KGST) and the TV station (KFTV Channel 21) "played the game" at specific times during week days using the newspaperprinted cards for the Loteria game. The Loteria images printed were selected on the basis of known driving problems in the farmworker community, such as driving in the fog, specific road signs and drinking and driving. In Campaign II, Vida en el Valle printed Loteria coupons with a Loteria card and a related driving quiz. Readers were instructed to complete, clip and deposit the coupons at one of four stores in the Fresno area. Coupons were then entered into a drawing for child safety car seats at a radio festival held on the Mexican holiday of Sept. 16.

In both campaigns, the radio outlet was the primary medium for play. Estimated voluntary contributions of onair radio time, for promotion, air-time and remotes, were more than $\$ 29,000$.

In the 1995 campaign, the game was played for a total of 3 weeks over a 5-week period. In the 1996 campaign, the Loteria was played for 4 consecutive weeks. Three times daily, a disc jockey announced the game, read the preselected rhymed verse and accepted calls in which the caller was required to identify the card. The "winners" became extenders of information for other listeners as they responded to questions that the DJ posed as part of the game. Many winners shared life stories and experiences related to driving. The DJ also reinforced messages from previous games. Winners received child-safety seats, copies of the game, T-shirts, hats, cassettes and other donated prizes. The value of the donated prizes in Campaign II exceeded $\$ 2,000$, including 28 car seats.

Winners were asked to leave their name, address and, when available, phone number for verification when they picked up prizes. Half of the winners were interviewed by phone 3 months after each campaign was completed. We selected these interviewees on a random basis from the list for phone interviews (table 1). A total of $13(48 \%)$ winners from Campaign I and $31(54 \%)$ winners from Campaign 
II were questioned as to how they learned about the campaign, recall of the card, title, theme, safety messages and reported behavioral changes. Using previously tested questions, a fluent Spanish speaker conducted the interviews in Spanish. Interviews were conducted at times convenient to the interviewees and lasted 30 to $45 \mathrm{~min}$ utes. Only limited elements of the interviews are reported here.

\section{Most heard the Loteria on radio}

The coupon clip-and-deposit technique of Campaign II proved to be of very limited use; fewer than three dozen entries were submitted over the full 12-week period.

The majority of winners first heard about the Loteria on the radio (54\% for I and $71 \%$ for II), supporting the assertion that radio is a popular medium commonly used by this population. The majority, 11 of 13 for Campaign I and 28 of 31 for Campaign II, correctly recalled and could name the particular card title originally identified several months earlier (table 1). The majority could also identify other card titles. Only 1 of all 44 interviewed was able to recall and repeat the more complex rhymed verse associated with their winning card. Only 3 of 13 winners from Campaign I could recall safety tips related to their winning card; 22 of $31(71 \%)$ of Campaign II winners correctly recalled their driving tips. In Campaign I, 6 of the 13 winners interviewed reported they or their spouses worked in agriculture. In Campaign II, 15 of the 31 winners reported agricultural work.

A possible explanation for the difference between the two groups may lie in the fact that during the 1996 campaign more detailed tips and information were provided to the radio station for use during the playing of the game. Also, the newspaper that published the cards and information did so over a longer period in Campaign II.
With regard to reported behavioral impacts, 10 of the 13 Campaign I winners and 20 of the 31 Campaign II winners reported a change in driving behavior (watching road signs, driving slower and so on), either in themselves or in a family member.

\section{Other assessments}

Other follow-up assessments were carried out at community festivals by groups of high-school students trained as program extenders (Stiles and Grieshop 1995, 1997). Prizewinners were interviewed after the community event or festival. Informal interviews suggested that safe-driving messages were learned and retained by participants.

In the case of media campaigns, due to limited financial resources and the complexity of verifying safe-driving behavior, we made no direct assessment of behavior change. For example, adequate funding was not available to determine if the program had affected behaviors such as use of seat belts or drinking and driving. Furthermore, control of the settings for assessing behavioral outcomes (i.e., efforts to observe before-and-after effects of training on driving practices) is difficult if not impossible.

Nevertheless, the media campaign assessments are vital and instructive. The two campaigns offered several advantages over the other events as targets for evaluation. First, the campaigns were carried out over an extended period of time ( 5 and 8 weeks with both newspaper and radio involvement) and in one general geographical setting. Also, the images and messages appeared in Spanish- and Englishlanguage newspapers for 8 weeks, then the game was played three times daily on the radio. Second, a limited number of specific messages were presented to the Spanish-speaking community through the print and electronic media, and these messages could be tracked. Third, participants who played and won the game on the radio were identifiable because winners had to leave their names and addresses to claim prizes. They were also informed that they might, with their permission, be contacted for follow-up information. In sum, the campaigns offered a realistic but not ideal situation for follow-up evaluation on outputs and outcomes.

\section{Implications of the program}

The acceptance of the Loteria game and the ¡Maneje Seguro! (Drive Safely!) program has been clear and concrete. Measures of that acceptance are observable in the intensity and attentiveness with which the target audiences played the game in festivals and trainings and through the media. The Loteria was popular not only with the farmworkers but also with the media and corporate firms involved. The ¡Maneje Seguro! program media campaigns affected the knowledge, awareness and, presumably to some degree, the motor-vehicle safety behaviors of individual farmworkers. The evaluation conducted with the winners of the media campaign games, a small and select sample, reveals significant recall of titles and driving tips. The respondents also report knowledge and attitude changes, along with noteworthy (but unverifiable) behavior changes.

However, community education campaigns such as this one do not usually "cause" sudden behavioral changes. The media campaigns, although targeted and intense, were limited in scope, frequency and time. Such efforts alone are probably not 
sufficient to bring about widespread change. Nevertheless, these campaigns attracted attention and were popular. To achieve demonstrable behavior changes, it will require more effort (for example, wider and more frequent media play, more community events) and more resources, and must be sustained over a longer period of time (Andreasen 1995).

The issues associated with behavioral change - whether of driving behavior, eating habits or use of new irrigation practices - are complex.

Educational approaches alone are limited in their effects. For example, low income levels for migrant farmworkers and families can be a major barrier to change. For a family with two or three children under the age of four, the cost of required child safety seats can be prohibitive. Income is also directly related to the age of an automobile and its condition. Another study carried out as part of the ¡Maneje Seguro! program revealed that more than half of the cars driven by a sample of 126 migrant families were manufactured before $1985 ; 82 \%$ were at least 7 years old (Stiles and Grieshop 1997).

Language, literacy and cultural practices also complicate the situation. As previously noted, most of the farmworkers and their families are Spanish-speaking and monolingual. In addition, many of the adults of driving age have low literacy levels in Spanish. The effects of low literacy become critical when installing child safety seats. If installed incorrectly (as happens with about $90 \%$ of all safety seats used by all groups, according to advocacy groups such as SafetyBeltSafe USA [Kim 1996]), the ability of child safety seats to protect children is reduced or even nullified. Printed instructions are difficult to understand (and often only in English), and misunderstandings increase with lower levels of literacy. Finally, seát belts and child safety seats are much less commonly available and used in Mexico, the home of many farmworker families. Therefore familiarity, as affected by cultural practice, is also an issue.

Educational approaches alone are useful, necessary and even powerful in affecting behavior. However, such approaches by themselves are seldom sufficient to ensure change. To reduce farmworker vehicle fatalities, an aggressive, comprehensive approach employing enforcement, engineering and education is necessary. Multiple parties must be involved, beginning with the worker and his or her family (Hamilton et al. 1995). The roles of law enforcement are essential, and in this situation potentially exert far more influence than education might. In addition, organizations such as Cooperative Extension, farm labor contractors, farm labor advocacy groups and farmers and farmer organizations must be actively engaged. Each has a unique but complementary role to play. Farm labor contractors and farmers have the opportunity to play educational and enforcement roles. They can demonstrate the need for safety belts and proper driving behavior, as well as ensuring that the vehicles they provide or that are used by workers are equipped with belts. They may offer support to retrofit cars. Others can assist by encouraging community organizations to provide loan programs for car safety seats or community clinics to repair and retrofit cars. Multiple interventions can be designed and implemented.

The impacts of this media-based program illustrate that culturally targeted, appropriate and acceptable educational approaches can play an active role in reducing unsafe driving in the Spanish-speaking populations, and particularly with the at-risk farmworker groups. The mix of approaches must include this variety in improved form as well. However, the designed interventions must incorporate education, engineering and enforcement. The continuing rate of crashes, injuries and fatalities involving farmworkers is tragic evidence of the ongoing need for such interventions.

J. Grieshop is Specialist and Lecturer in Community Education Development in the Department of Human and Community Development, UC Davis; $M$. Grajales-Hall is Spanish Language Media Representative, Division of Agriculture and Natural Resources, UC Riverside; and L. Ortiz was Postgraduate Researcher in the Department of Human and Commu- nity Development, UC Davis, located in Fresno.

The authors gratefully acknowledge the work, creativity, and contributions of Jenny Rodriguez and Martha Stiles to the early research on the issue of motor vehicle safety and farmworkers and the design and production work of La Loteria del Manejo Seguro.

Car seats for La Loteria were donated by Midas Muffler, Zenith Insurance, AgSafe and local businesses and individuals.

\section{References}

AgSafe. 1992. Occupational Injuries in California Agriculture 1981-1990. AgSafe Coalition for Health and Safety in Agriculture. School of Public Health, U.C. Berkeley. $24 \mathrm{p}$.

Andreasen A. 1995. Marketing for Social Change. Jossey-Bass: San Francisco, CA. $348 \mathrm{p}$.

[CHP] California Highway Patrol. 1993. (SWITRS) StateWide Integrated Traffic Record System Report: 1993. California Highway Patrol: Sacramento, CA.

Clemings, Russell. 1996. Fatal van crash prompts call for farmworker safety laws. The Fresno Bee: Fresno, CA. May 18, 1996: B1,2.

Grieshop JI, Stiles M. 1994. Hispanic Traffic Safety Training System: A Bilingual, MultiMedia Program for Semi- and Non-Literate Drivers. Memorandum Proposal to the California Office of Traffic Safety. University of California, Davis: Davis, CA. 7 p.

Hamilton A, Arias A, and Acosta A. 1995. Highway Safety Needs of U.S. Hispanic Communities: Issues and Strategies. (Report No. DOT HS 808 373) U.S. Department of Transportation, National Highway Traffic Safety Administration, Washington, D.C. September 1995. $159 \mathrm{p}$.

Kim C. 1996. Family Safety in the Car. SafetyBeltSafe U.S.A.: Altadena, CA. Mimeo: $3 \mathrm{p}$.

Martin P. 1992. Farm labor in California: past, present, and future. A supplementary report for the Farm Worker Service Coordinating Council. Sacramento, CA. $33 \mathrm{p}$.

Stiles M, Weeks KL, Rodriguez J, et al. 1994. La Loteria del Manejo Seguro/Motor Vehicle Safety: The Game. Publication No. 3363. ANR Publication, University of California: Oakland, CA.

Stiles M, Grieshop JI. 1995; 1996. OTS Quarterly Reports (various): University of California, Davis: Davis, CA.

Stiles M, Grieshop Jl. 1997. ¡Cuidado! Cultural Considerations for Traffic Safety. Department of Human and Community Development, UC Davis, CA. Paper for Lifesavers 15 Conference, Orlando, FL. June 8-11, 1997. $8 \mathrm{p}$.

Strategy Research Corporation. 1996. 1996 U.S. Hispanic Market. Strategy Research Corporation: Miami, FL. 374 p. 